\title{
Keynes and modern macroeconomics
}

\author{
Willi Semmler \\ Department of Economics and Research Fellow at the Schwartz Center for Economic Policy \\ Analysis, New School, New York, and Center for Empirical Macroeconomics, Bielefeld \\ e-mail: semmlerw@newschool.edu \\ Gang Gong \\ Department of Economics at Tsinghua University, Beijing \\ e-mail:gongg@em.tsinghua.edu.cn
}

\begin{abstract}
Recently, the dynamic general equilibrium (DGE) model, or its more popular version, the Real Business Cycle Model, has become a dominant paradigm in macroeconomics. Also many New Keynesians have embraced this new paradigm. Keynes in his General Theory has extensively responded to and criticized classical economics that was dominant at his time. This paper elaborates on how Keynes would have responded to this new paradigm. Moreover, we discuss some major macroeconomic issues and show of how differences in traditional Keynesian and the DGE models may arise. We also elaborate of why certain Keynesian ideas can usefully be applied to modern macroeconomics which may help to resolve some important puzzles of modern macroeconomic theory.
\end{abstract}

Key words: Keynesian economics, DGE models, non-clearing markets, business cycles.

JEL classification: E0, E2, E3, E24.

"Our present is determined as much by where we want to go as it is by where we have come from" (Ernst Bloch, German philosopher).

\footnotetext{
* This paper is complementary to the paper by Edward Nell presented in the symposium "70 Years after the General Theory" held in Ankara, 1-2 December 2006. We want to thank Edward Nell for helpful discussions and comments.
} 


\section{Introduction}

Keynes in his General Theory has extensively responded to and criticized classical economics that was dominant at his time. This paper elaborates on how Keynes would have responded to the dynamic general equilibrium (DGE) model, or its more popular version, the Real Business Cycle (RBC) Model, that appears to dominate macroeconomics today. Recently many New Keynesians have also embraced this new paradigm in macroeconomics. In this paper we will discuss some major macroeconomic issues and show how differences in traditional Keynesian and the DGE models may arise. This paper is based on Gong and Semmler (2006a). There, a further more detailed study can be found of why certain Keynesian ideas can usefully be applied to modern macroeconomics which may help to resolve some important puzzles of modern macroeconomic theory.

The DGE model has become a major paradigm in the graduate education of macroeconomics in the US. It has impacted the profession a lot and it has been applied in numerous fields of economics. ${ }^{1}$ Its essential features are the assumptions of intertemporal optimizing behavior of economic agents, competitive markets and price-mediated market clearing through --- at least in most versions -flexible wages and prices. In this type of stochastic dynamic macro modelling real shocks, such as technology shocks, fiscal policy shocks and shifts in preferences can generate macro fluctuations. Recently models with nominal shocks such as monetary policy shocks have also been considered, but these are still in a early stage of exploration.

Moreover, some Keynesian features have been built into the DGE model by keeping its basic characteristics such as intertemporally optimizing agents and market clearing, but introducing monopolistic competition and sticky prices and wages into it. In particular, in numerous papers and in a recent book, Woodford (2003) has worked out this new paradigm, which is now commonly called New Keynesian macroeconomics. In contrast to the traditional Keynesian macro models, such variants also presume dynamically

\footnotetext{
1 Of course, there are many, "more Keynesian" perspectives on modern macroeconomics which are not built on intertemporally optimizing agents, but we here do not want to touch upon those alternative paradigms. See Chiarella et al. (2006) for such an alternative paradigm.
} 
optimizing agents and market clearing, but sluggish wage and price adjustments. ${ }^{2}$

It is well known that the standard DGE model fails to replicate essential product, labor and financial market characteristics. Keynesian tradition, different from the DGE model either in its competitive or monopolistic economy variant, does not presume clearing of all markets in all periods. As in the monopolistic competition variant, we can permit nominal or real rigidities; yet, by stressing Keynesian features in a model with production and capital accumulation, we can build models that even with dynamically optimizing agents all markets are not cleared. Subsequently we will discuss a series of issues that are at the heart of modern macroeconomics, but are hard to be resolved from the perspective of the DGE model or New Keynesian economics. We will speculate on how Keynes would have responded to those unresolved issues.

The remainder of the paper is organized as follows. Sect. 2 of the paper discusses some major macroeconomic topics and how the puzzles arising there may be resolved by employing more of a Keynesian perspective. Sect. 3 then moves forward to an essential issue that modern macroeconomics has posed and which was extensively studied already in Keynes, in his General Theory. This is the role of expectations which essentially refers to the role of the past and the future in economic behavior. Sect. 4 concludes the paper.

\section{Some modern macroeconomic issues}

The macroeconomic issues we discuss here were, to some extent, discussed in the 1920s and 1930s before and after Keynes attempted to move macroeconomics away from classical economic postulates in order to give macroeconomics a better foundation. Many of the issues immediately became the focus of discussions after the General Theory was published. Yet, we here pick a few topics that have become relevant in recent years in response to the development of new classical economics in the form of the DGE model, which has taken, as compared to the classical economics in the times of Keynes, an intertemporal and thus more dynamic perspective. Yet the issues remain similar ones.

2 See also the volume in honor of Edmund Phelps, edited by Aghion et al. (2003) where in particular informational problems are stressed. It should, however, be noted that the concept of market clearing in recent New Keynesian literature is not unambiguous. We will discuss this issue later. 


\subsection{Equilibrium models versus market dynamics}

Nowadays equilibrium models appear in the form of intertemporal equilibrium models, or dynamic equilibrium models. We first want to briefly discuss the intertemporal equilibrium model, the DGE model, as a benchmark and then show how New Keynesian Economics is related to this development. As aforementioned, the DGE model is also often known under the more popular name, the RBC model. We start with this paradigm in order to compare it with the Keynesian tradition. A more detailed statement of the essential three marginal conditions on which the benchmark model is built -and Keynes' likely response to them -- can be found in Appendix 1 .

The standard DGE model is a representative agent model, constructed on the basis of neoclassical general equilibrium theory. It therefore assumes that all markets (including product, capital and labor markets) are cleared in all periods regardless of whether the model refers to the short- or the long-run. The imposition of market clearing requires that prices are set at equilibrium levels. At the pure theoretical level, the existence of such general equilibrium prices can be proven under certain assumptions. Little, however, has been told how the general equilibrium can be achieved. Market dynamics are disregarded in an economy, in which both firms and households are price-takers; implicitly, an auctioneer is presumed to exist who adjusts the price towards some equilibrium. Thus, the way of how an equilibrium is brought about in the DGE model is essentially a Walrasian tâtonnement process which quickly clears markets. The issue of stability of market adjustment processes as has extensively been explored in earlier literature ${ }^{3}$ is not studied anymore in the DGE model.

Working with such a competitive general equilibrium framework is elegant and perhaps a convenient starting point for economic analysis. It nevertheless neglects many restrictions on the information and behavior of agents, the constraint that agents face, the trading and the market clearing process, the creation and implementation of new technology and the market structure, among many others. We later go into details of the standard RBC model, the representative stochastic dynamic model of competitive general equilibrium type, when we come to certain topics. We want to lay out the micro foundations and a variety of topics related to it, but we also

3 Hahn (1982) gives an extensive survey on the history of the modeling of market dynamics the study of which is missing in modern DGE models. 
want to discuss a variety of empirical issues, for example the matching with the empirical data, its financial market implications and so on. The discussion of those issues give incentives to elaborate and introduce Keynesian features in modern macroeconomics. Meanwhile, this also provides a reasonable ground to judge new model variants by considering whether they can resolve some puzzles better than the DGE model.

\subsection{Unique equilibrium versus open-ended dynamics and multiple equilibria}

Due to the concavity of preferences and convexity of production sets the standard DGE model implies that there exists only a unique equilibrium, or, if there is stochastic growth, the economy fluctuates about some stochastic steady-state, driven by stochastic technology shocks. The economy will always return to the vicinity of that steadystate. In this view, policies (such as fiscal or monetary policies) can only be distortionary, and thus should be reduced to a minimum, for example restricted to smoothing tax rates. Often, it is also demonstrated, by using first or second order approximation methods to solve the DGE model, that after disturbances by stochastic shocks neither the choice variables, such as consumption, nor the welfare functions, such as households` welfare, are significantly disturbed by stochastic shocks and the nearby equilibrium solutions are always approximately "good solutions". For a further elaboration and critical evaluation of this point, see Becker et al., (2007).

On the other hand, in Keynes equilibrium analysis is not pursued, rather he uses the concept that the economy is in long term position. Yet, the long term position in Keynes depends on expectations and, as Keynes (1936: Ch. 5) shows, there is not only one unique long term position, but possibly a multiple of them. There is, as Keynes views the evolving economic process, an open-ended dynamics. This can arise from expectations, externalities and increasing returns, from real frictions etc., all possibly giving rise to multiple long run positions for actual economies.

To illustrate this point we here simply refer to real frictions, arising from adjustment cost. A model of this type is sketched in Appendix 2. In the standard DGE model firms do not face any additional cost (a cost beyond the usual activities at the current market prices) when they make adjustments on either price or quantity. For example, changing the price may require the firm to pay a menu cost and also, more importantly, a reputation cost. It is the cost, arising 
from price and wage adjustments that has become an important focus of New Keynesian research over the last decades. ${ }^{4}$ However, there may also be adjustment cost from a change in quantities. In a production economy increasing output requires the firm to hire new workers and add new capacity. In a given period of time, a firm may find more and more difficulties to create new additional capacity. This indicates that there will be an adjustment cost in creating capacity (or capital stock via investment), and further such adjustment cost may also be an increasing function of the size of investment For details of such a model, see Kato et al. (2006).

In Gong and Semmler (2006a: Ch. 7), we introduce adjustment costs into a DGE model and show how this may bring about multiple equilibria toward which the economy may move. The details are described in Appendix 2. ${ }^{5}$ As in Keynes, the dynamics are open-ended in the sense that the economy can move to low level, or high level of economic activity. ${ }^{6}$ Such an open-ended dynamics is certainly one of the important features of Keynesian economics. In recent times such open-ended dynamics have been found in a large number of dynamic models with intertemporal optimization. Those models have been called indeterminacy and multiple equilibria models. Theoretical models of this type are studied in Benhabib and Farmer (1999) and Farmer (1999), and an empirical assessment is given in SchmidtGrohe (2000). Some of the models are real models, RBC models, with externalities and increasing returns to scale and/or more general preferences than power utility that generate indeterminacy. Local indeterminacy and globally a multiplicity of equilibria can arise here. Others are monetary macro models, where consumers' welfare is affected positively by consumption and cash balances and negatively by the labor effort and an inflation gap from some target rates. For certain substitution properties between consumption and cash holdings, those models admit unstable as well as stable high-level and low-level steady-states. In the neighborhood of one of those latter steady-states then there can be indeterminacy in the sense that any

4 Important papers in this research line are, for example, Calvo (1983) and Rotemberg (1982). For a recent review, see Taylor (1999) and Woodford (2003: Ch. 3).

5 See also Kato et al. (2006).

6 Keynes (1936) indeed discusses the possibility of such an open-ended dynamics in Chapter 5 of his book where he elaborates on the possibility of a multiplicity of long period positions. There, however, Keynes seems to use a combination of both arguments, namely expectations and real frictions, where the present is locked into decisions of the past. 
initial condition close to such a steady-state can lead toward, or away from, that steady-state, see Benhabib et al. (2001).

Overall, the indeterminacy and multiple equilibria models predict an open-ended dynamics, arising from sunspots, where the sunspot dynamics are frequently modeled by versions with multiple steady-state equilibria, and where there are also pure attractors (repellers), permitting any path in the vicinity of the steady-state equilibria to move back to (away from) the steady-state equilibrium. In these types of models with multiple equilibria one correspondingly speaks of "local indeterminacy". All of these are important variants of macrodynamic models with optimizing behavior; however, as recently has been shown, ${ }^{7}$ indeterminacy is likely to occur only within a small set of initial conditions. Yet, despite such unsolved problems, the literature on open-ended dynamics has greatly enriched macrodynamic modeling and can ultimately be traced back to some of Keynes' ideas in his General Theory (1936: Ch. 5).

Pursuing this line of research in Gong and Semmler (2006a: Ch.7) we have introduced a simple model where one does not need to refer to model variants with externalities and increasing returns to scale and/or to more elaborate preferences or expectations dynamics to obtain such results. We show that due to the adjustment cost of capital we may obtain non-uniqueness of steady-state equilibria in an otherwise standard dynamic optimization version. Multiple steadystate equilibria, in turn, lead to thresholds separating different domains of attraction of capital stock, consumption, employment and welfare level. As our solution shows, thresholds are important as separation points below or above which it is advantageous to move to lower or higher levels of capital stock, consumption, employment and welfare. Our model version thus can explain of how the economy becomes history dependent and moves, after a shock or policy influences, to a low or high level equilibria in employment and output. A further important feature of Keynesian economics is non-clearing markets.

\subsection{Market clearing versus non-clearing markets}

As mentioned above, an important characteristic of the DGE model is that it is a market clearing model. This, in particular, is puzzling concerning the labor market. Indeed, even for the labor market the DGE model predicts that the labor market is cleared at all points in time. As a result of a smooth decision process of labor

\footnotetext{
7 See Grüne and Semmler (2004).
} 
supply and leisure choice by households, establishing the marginal conditions as stated in Appendix 1, an excessive smoothness of labor effort and thus employment is implied. This is in contrast to what one finds in empirical data. This has become one of the major well-known puzzle in the RBC literature. ${ }^{8}$ It is indeed related to the specification of the labor market as a cleared market. Though in its structural setting, (see, for instance, Stockey et al., 1989), the DGE model specifies both the demand and supply sides of a market, the moments of the macro variables of the economy (and thus equilibrium in all markets, including output, labor and capital markets) are, however, generated by a one-sided force due to its assumption on wage and price flexibility. The labor effort results only from the decision rule of the households to supply labor. In our view there should be no restriction for the other side of the market, the demand, to have effects on the variation of labor effort.

Attempts along those lines have been made to introduce imperfect competition features into the DGE model. ${ }^{9}$ In those types of models, producers set the price optimally according to their expected market demand curve. If one follows a Calvo-type price setting scheme, there will be a gap between the optimal price and the existing price. However, the producer is assumed to supply the output according to what the market demands for the existing price. This consideration also holds for the labor market. Here the wage rate is set optimally by the household according to the expected market demand curve for labor. Once the wage has been set, it is assumed to be rigid (or adjusted slowly). Thus, if the expectation is not fulfilled, there will be a gap again between the optimal wage and existing wage. Yet in the New Keynesian models the market is still assumed to be cleared since the household is assumed to supply labor whatever demand is at the given wage rate. ${ }^{10}$

In order to better fit the predictions with the labor market data, search and matching theory has been employed to model the labor market in the context of DGE models. Informational or institutional search and matching frictions may then explain equilibrium unemployment rates and its rise. Yet, those models still have a hard

8 A recent evaluation of this failure of the RBC model is given in Schmidt-Grohe (2001).

9 Rotemberg and Woodford (1995, 1999), King and Wollman (1999), Gali (1999) and Woodford (2003) present a variety of models of monopolistic competition with price and wage stickiness.

${ }^{10}$ Yet, this definition of market clearing is not unambiguous: markets must be noncleared if prices or wages are not optimally adjusting in each instant of time. 
time to explain the large variation of vacancies and unemployment and the strong shift of unemployment rates such as, for example, experienced in Europe since the 1980s, as equilibrium unemployment rate. ${ }^{11}$

Concerning the labor market we need to pursue an approach along Keynes' line of his General Theory (1936: Ch. 2) that allows for a non-clearing labor market. In Appendix 1 we show that the Keynes' criticism of the classical postulates for clearing labor markets can be re-applied to modern macroeconomics of general equilibrium type. In Appendix 1 it is also demonstrated that the non-acceptance of the classical postulates will lead to a non-clearing labor market. In our view it is the presumption of the smooth, frictionless and unrestricted choice of households -and firms- that generate those classical equilibrium conditions, which however is in stark contrast to the actual working of the labor markets and households' choice of labor effort and consumption under market constraints.

In our view as sketched in the model in Appendix 3, the decisions with regard to price and quantities are made separately; both can be subject to optimal behavior. When the price has been set, and is sticky for a certain period, the price is then given to the supplier when deciding on the quantities. There is no reason why the firm cannot choose the optimal quantity rather than what the market demands, especially when the optimum quantity is less than the quantity demanded by the market. This consideration will allow for nonclearing markets. ${ }^{12}$ Based on this idea, one can develop a model which helps to study labor market problems where households, after a first round of optimization, have to reoptimize when facing constraints in supplying labor to the market (see Gong and Semmler, 2006b). On the other hand, firms may face constraints on the product markets. As we have discussed in Gong and Semmler (2006a: Chs. 8-9; 2006b), such a multiple stage optimization model will allow for a more realistic description of fluctuation of the unemployment rates as compared to the standard DGE model, and it provides also a framework to study the secular rise or fall of unemployment. Details of such a model of non-clearing labor markets, are sketched in Appendix 3.

${ }^{11}$ For an evaluation of the search and matching theory as well as the role of shocks to explain the evolution of unemployment in Europe, see Ljungqvist and Sargent (2003) and Blanchard (2003).

12 There is indeed a long tradition of macroeconomic modeling with specification of the non-clearing labor markets; see, for instance, Benassy $(1995,2002)$ and Malinvaud (1994). Although our approach owes a substantial debt to disequilibrium models, we move beyond this type of literature; see Appendix 2 for details. 


\subsection{Technology versus demand shocks}

In the standard DGE model technology shocks are the driving force of the business cycles which is assumed to be measured by the Solow-residual. Since the Solow residual is computed on the basis of observed output, capital and employment, it is presumed that all factors are fully utilized. There are several reasons to distrust the standard Solow residual as a measure of technology shock. First, Mankiw (1989) and Summers (1986) have argued that such a measure often leads to excessive volatility in productivity and even the possibility of technological regress, both of which seem to be empirically implausible. Second, it has been shown that the Solow residual can be expressed by some exogenous variables, for example demand shocks arising from military spending (Hall, 1988) and changed monetary aggregates (Evans,1992), which are unlikely to be related to factor productivity. Third, the standard Solow residual can be contaminated if the cyclical variation in factor utilization are significant.

Considering that the Solow-residual cannot be trusted as a measure of technology shock, researchers have now developed different methods to measures technology shocks correctly. All these methods are focused on the computation of factor utilization. There are basically three strategies. The first strategy is to use an observed indicator to proxy for unobserved utilization. A typical example is to employ electricity use as a proxy for capacity utilization (see Burnside et al., 1996). Another strategy is to construct an economic model so that one could compute the factor utilization from the observed variables (see Basu and Kimball, 1997 and Basu et al., 1998; 1999; 2006). A third strategy uses an appropriate restriction in a VAR estimate to identify a technology shock, see Gali (1999), Gali and Rabanal (2004), and Francis and Ramey (2001, 2003).

It is well known that one of the major celebrated arguments of real business cycles theory is that technology shocks are pro-cyclical driving the business cycle. A positive technology shock will increase output, consumption and employment. Yet this result is obtained from the empirical evidence, in which the technology shock is measured by the standard Solow-residual. As Gali (1999) and Francis and Ramey (2001, 2003) we also find that if one uses the corrected Solowresidual, the technology shock is negatively correlated with actual employment and therefore the RBC model loses its major driving force, see Gong and Semmler (2006; Chs. 5 and 9). More Keynesianoriented researchers have stressed that non-technology shocks could 
be due to imperfect competition, non-constant returns to scale and in particular due to the utilization of capital and labor services. The latter driving forces for the Solow-residual could be all summarized as effects arising from demand shocks as for example Gali and Rabanal (2004) described it.

In sum, as recent empirical literature has shown, factors affecting the Solow-residual, studied by the more Keynesian-oriented literature -and which are defined more or less as demand shocks- can account for at least half of technology shock as measured by the Solow-residual. The DGE model predicts a significantly high positive correlation between technology and employment. Yet, empirical research demonstrates, when the technology shock is "cleaned" by taking out the effect of the demand shock, that at least at business cycle frequency, a negative or zero correlation between technology and employment exists (see Gali, 1999; Gali and Rabanal, 2004 and Francis and Ramey, 2001; 2003). This at least holds for the medium run over the business cycle. Empirical research has also shown that a pure technology shock -cleaned from its demand component- has a positive effect on employment only in the long run. ${ }^{13}$

A further recently raised issue are the short and long run effects of demand shocks, as it is stressed to be the driving force of the business cycle by Keynesian theory. Traditionally technology shocks have been seen to only have persistent effects on output. In this view demand shocks have only a short run effect, not affecting output and employment in the long run. This is not only presumed in neoclassical supply side theory but is also presumed in recently used VAR tests with supply and demand shocks. Blanchard and Quah (1987) for example presume that supply shocks have a permanent effect on output, but not so demand shocks. The latter have transitory but not lasting effects on output. Gali (1999) and Gali and Rabanal (2004) study productivity shocks and employment in VAR and assume that demand shocks have no lasting effects on productivity. ${ }^{14}$

The above position of no lasting effect of Keynesian demand shocks is also often replicated in monetary policy studies, where it is usually assumed that monetary policy shocks have only temporary but no persistent effects. Yet, following Tobin, Blanchard (2005) shows

\footnotetext{
${ }^{13}$ There is empirical evidence now that technology shocks will affect positively not only output but also reduce unemployment in the long run, and thus increase employment; see Khemraj, Rezai and Semmler (2006) and Pu et al. (2007).

${ }^{14}$ The short and long run productivity effects are further discussed in Khemraj, Rezai and Semmler (2006).
} 
that monetary policy affects persistently both the real interest rate as well as the real activity and employment.

Yet, some presumed lasting and persistent effects on output and employment (if the latter relationship follows Okun's Law and does not change in the long run $)^{15}$ needs some theoretical foundation. As discussed above (and as further detailed in Gong and Semmler, 2006a: Ch. 8), one can presume that households demand for goods may be constrained by the firms' actual demand for labor. This way households also constrain the product market in buying less consumption goods than firms would like to have bought. In Gong and Semmler (2006a: Ch. 8), the non-cleared labor market is derived from a multiple stage decision process of households facing constraints in the labor market; but firms are also likely to be constrained in the product market. This additional complication can arise due to the interaction of the labor market and the product market constraints.

If firms, however, face constraints on the product market, this may explain the technology puzzle, namely that positive technology shocks may have a negative effect on employment in the short run - a phenomenon inconsistent with equilibrium business cycle models, where technology shocks and employment are predicted to be positively correlated. This result is also often obtained in an economy with monopolistic competition, as in New Keynesian economics, where prices and wages are set by a monopolistic supplier and are sticky, resulting in an updating scheme of prices and wages where only a fraction of prices and wages are optimally set each time period.

Yet we can, as above mentioned, also introduce a non-clearing labor market, resulting, as demonstrated in Appendix 2, from a multiple stage decision problem, where the households' constraint on the labor market spills over to the product market and the firms' constraints on the product market generates employment constraints. We indeed can show that such a model matches better time series data of advanced economies such as the US and the Euro area, see Ernst $e t$ al. (2006). If this is the case, increase of demand becomes important and it may have persistent effects. As to our knowledge, the lasting effects of demand shocks have not been studied in terms of a VAR methodology.

\footnotetext{
${ }^{15}$ For a detailed discussion of this point, see Khemraj, Madrick and Semmler (2006).
} 


\subsection{Smooth asset markets versus financial market volatility}

We may say that the standard DGE model has left us with another major puzzle. This puzzle is related to the asset market and the volatility of asset prices which is often discussed under the heading of the equity premium puzzle which cannot be explained by the standard DGE asset pricing theory; for more details, see Semmler (2006). Extensive research has been pursued on this problem by elaborating on more general preferences and technology shocks. Usually consumption-based asset pricing models are used to explain the equity premium and volatility of asset prices. Using power utility or habit formation in consumption and adding other real frictions such adjustment cost of capital are not sufficient to give an equity premium of sufficient size; see Grüne and Semmler (2007). In the DGE tradition, asset price movements and financial market volatility reflect real rigidities and real shocks. Financial market shocks do not play any independent role. If some feedback from asset price volatility to preferences is introduced (as done in recent theories of loss aversion), some progress can be made; see Grüne and Semmler (2008).

This deficiencies of the DGE models with respect to modern financial market facts has early been recognized by Bernanke and Gertler (1989) and Bernanke et al. (1998), who have built models with credit and imperfect capital markets. Here then the financial accelerator, in addition to the real accelerator, is introduced to explain the role of financial markets for macroeconomic activity. Credit constraints and/or state-dependent risk premia for credit, which are derived from information and screening cost, reflecting a financial risk premium or default premium, can magnify a real shock so that the financial accelerator impacts both the upturn as well as the downturn of the economy. In upturns the collateral is higher and thus risk premium lower and in downturns the collateral is lower and thus risk premium higher. The financial side of the economy acts procyclically, magnifying business cycles. A further extension of those types of models is provided in Grüne and Semmler (2005) where it is shown that risk premia also affect asset pricing and thus the value of the collateral itself, which implies that the famous Modigliani-Miller theorem would not hold when firm value, and thus the collateral, becomes endogenous.

Those models that broke away from the neutrality of debt finance -and which have implicitly introduced credit and debt finance in macro models- originate in Kalecki`s (1937) "principle of increasing risk". Although Keynes (1936: Ch. 8) has dealt with credit 
and debt only rudimentarily in his General Theory, it was in particular, Kalecki (1937), Gurley and Shaw (1960) and then later Minsky $(1976$; 1978) who have taken the study of debt finance as crucial for modern investment theory and macro dynamics. Minsky has built up the modern theory of financial fragility; for details, see Semmler (2006: Chs. 4-6). Financial fragility theory has recently not only been applied to explain the important role of the financial sector in advanced economies but appears to be also very relevant in emerging markets as well, see Frankel (2005).

3. An overall evaluation: The role of the future in Keynes

As aforementioned, stochastic dynamic modelling strategies of forward looking type have become important in macroeconomics. As discussed also above, this type of macroeconomics has produced major puzzles. Most of the puzzles have to do something with the role of the future in economic decisions. Rational expectations revolution has overly stressed the role of perfect anticipation of the future in economics. On the other hand traditional Keynesian economics has often neglected the role of the future. So what we want to discuss here is Keynes' view of the future that is substantively different from how the rational expectation school sees it.

Earlier, in the 1920s and 1930s Hayek, Keynes and Knight tried to explain aggregate outcome in reference to individual behavior where individual market agents form some expectations on the future with limited and imperfect knowledge of the future. We would like to argue that the role of the future is important in economic decisions and has been substantially dealt with by Keynes.

The first important aspect is the decision under uncertainty and the way how some knowledge on the future is obtained and decisions are made. Keynes, meant that the future is only incompletely accessible through probabilistic and statistical calculations. Keynes says: "We are merely reminding ourselves that human decisions ...., cannot depend on strict mathematical expectation, since the basis for making such calculations does not exist; and ... that our rational selves [are] choosing between alternatives as best as we are able, calculating where we can, but often falling back for our motive on whim or sentiment or chance." (Keynes, 1936: 162) What this description of individual decision-making actually means that rational individuals would adopt forecasting strategies that, in general, include factors, 
formal or informal, which cannot be adequately represented by the standard statistical theory. ${ }^{16}$

A second important aspect of Keynes' thinking about the decision under an uncertain future is that agents act under market constraints when the decisions are attempted to be implemented. ${ }^{17} \mathrm{We}$ want to argue that it is not necessarily in contradiction to Keynes to pursue dynamic macroeconomic models with adaptively rational agents, but we do not need to presume perfect knowledge and clearing of all markets at all times. Agents act under the constraints that markets are not cleared. As shown above, to allow for non-clearing markets, we can introduce a multiple stage adaptive decision process where agents can reoptimize when facing such market constraints. We have argued in Gong and Semmler (2006a) that intertemporal behavior by adaptive rational agents are not in contradiction to a Keynesian view on the working of modern macroeconomies if the market constraints are properly taken into account.

A third important aspect is Keynes' concern with the link between individual decisions and aggregate outcome. Keynes in fact recognizes that agents are adaptively rational and do attempt to optimize, but he distinguishes between individual intertemporal rational behavior and aggregate behavior and outcome. The latter, in his view, should be the focus of macro policy. As regards saving and consumption, he demonstrates that individual saving will be undertaken rationally, among other motives, in order to build up assets for future consumption or to secure resources to carry out further investment. $^{18}$ On the other hand, in Keynes' view, aggregate consumption and saving has to strike a delicate balance between the past and the future. He argued that an increase in saving by a reduction of current consumption will reduce effective demand and will reduce employment; but it will have this effect only as much as it is not accompanied by an increase of expected future consumption and investment stimulating current output and employment. Thus current consumption is seen to represent a link between the past (linked to past output and income) and the future. ${ }^{19}$

Investment is driven by prospective yields depending on future effective demand. Saving and investment lead to future consumption

\footnotetext{
${ }^{16}$ For a further exploration of this aspect, see Frydman and Goldberg in Aghion et al. (2003).

17 This is an aspect that in particular Richardson (1960) has stressed.

${ }^{18}$ See Keynes (1936: Ch. 9)

${ }^{19}$ See Keynes (1936: Ch. 8 and Ch. 16)
} 
and thus to stimulation of investment and output, but it also leads to lower current consumption endangering current demand and employment. Whether or not reduction in aggregate consumption and increase in savings will be expansionary or contractionary depends on income expectations of households and on the expectations of the valuation of firms' capital assets. Concerning expectations, Keynes stresses that not only is the current state of capital equipment and technology related to various past states of expectations, but there may be a multiplicity of future long run positions generated by the dynamics of expectations and lock-in effects from the past, ${ }^{20}$, a topic that we have discussed above in Sect. 2.

Moreover, although price and wage flexibility may be advantageous for the individual agent, aggregate behavior may be destabilized by the fluctuations of aggregate prices and wages. ${ }^{21}$ In fact in Keynes sticky wages and prices are perceived to be stabilizing. Although Keynes does not believe that large fluctuations in unemployment can be derived on the basis of the classical postulates (and are thus not voluntary or frictional), he is ambiguous what the causes are of persistent unemployment - whether it comes from protracted periods of disequilibrium or is an equilibrium phenomenon (so that the economy got stuck at a low level equilibrium).

In responding to such issues, in the modelling strategy in Gong and Semmler (2006a: Chs. 8-9) we have worked out model variants with sticky prices and wages, as perceived in Keynes. With the use of some ideas by Keynes, one can employ the assumption of dynamic decision making under imperfect knowledge and market constraints. As we have shown above, this might help us to improve on the modern labor market puzzles. An important extension is to make wage adjustments endogenous, such as for example proposed in Uhlig (2004) and as in Gong and Semmler (2006b) where wage rates respond to past wage rates and employment. We think that such a modelling of wage and price setting is essential for future work on the labor market.

Let us suppose adaptive rational optimization behavior of economic agents. We have shown that, on the one hand, households' demand for consumption goods reflects optimal decisions concerning the future paths of technology and capital stock; households, on the other hand, also respond to current employment and thus firms are

${ }^{20}$ See Keynes (1936: Ch. 5)

${ }^{21}$ See Chiarella et al. (2006). 
also likely to be constrained by the current households decisions on the product market. The latter phenomenon was discussed above where we have argued that, given demand constraints for firms on the product market, it appears as reasonable that technology shocks may have negative effects in the short and medium run on employment. Such a model of constrained labor and product markets may help to explain the technology puzzle of standard RBC models where technology shocks are procyclical and increase employment. In our context, although technology shocks are likely to be positively correlated with employment in the long run, in the short and medium run it may have adverse effects on employment, if there are simultaneously labor and product market constraints which were a major concern for Keynes.

We know that assuming a dynamic decision framework and intertemporal optimizing behavior for agents is not uncontroversial in the Keynesian tradition. It is, in particular, controversial when a single agent's dynamic optimization behavior is posited to hold for the macroeconomy - as in the representative agent RBC model - to also hold for the aggregate behavior. As Keynes warns us, the individual optimal choice does not necessarily result in socially preferred outcomes. Social aggregate choices and policies may be needed to complement individual behavior. ${ }^{22}$ Yet, taking this qualification into account, intertemporally optimizing behavior of households may be a useful first approximation of aggregate behavior as well.

As has been recently pointed out this view can also provide one with an interesting framework ${ }^{23}$ to study growth regimes, or eras, where certain preferences and technologies prevail, but may change over time. For countries there may be distinct differences over time of growth regimes that suggest substantial changes of consumption, saving and technology, the outcome of which may be measured by some welfare function in which more variables enter than the per capita income.

As mentioned above in Sect. 2, research along the line of Keynesian micro-oriented macroeconomics has been historically developed by two approaches: one is the tradition of non-clearing market (or disequilibrium analysis), and the other is the New Keynesian analysis of monopolistic competition and sticky prices and wages. These two approaches are relevant historical traditions. One

${ }^{22}$ See Keynes (1936: Ch. 24)

${ }^{23}$ An excellent framework for such a study is developed in Day and Young (2004). 
can improve on the labor market, technology and other macroeconomics puzzles, if we combine these two approaches in a dynamic decision framework. We want to argue that the two traditions can indeed be complementary rather than exclusive, and therefore they can somewhat be consolidated into a more complete system of price and quantity dynamics within the Keynesian tradition.

The main new method we need here to reconcile the two traditions is a multiple stage adaptive rational behavior with updating of information, where agents revise decisions once they have perceived and learned about market constraints. Thus, adaptive behavior permits us to properly treat the market adjustment for nonclearing markets which, we hope, allows us to make some progress to match better macro models with time series data.

Finally we want to note that those dynamic decision models are often difficult to solve. Macroeconomic researchers mostly focus on approximate solutions, computed from first order conditions. Often linearization or log-linearization of the first order conditions are used; although recent methods sometimes suggest taking second order approximations as well for the evaluation of policy shocks, in particular if the shocks are large, such as tax changes ${ }^{24}$. We want to note here that the method used in Gong and Semmler (2006a; 2006b) appears to be sufficiently accurate to supply a multiple stage decision model by which the working of noncleared labor and product markets can be understood and also empirically evaluated. ${ }^{25}$

\section{Conclusions}

The DGE model reduces macroeconomics to the frictionless, smooth and unconstrained decision making of dynamically optimizing agents. New Keynesian economics reduces the Keynesian contribution to macro economics to the role of sticky wages and prices for macroeconomics. They tend to accept the equilibrium framework of the DGE models for modelling phenomena of modern macro economics and fiscal and monetary policy effects. We think we can

\footnotetext{
${ }^{24}$ See Schmidt-Grohe and Uribe (2004).

${ }^{25}$ For the equilibrium approach, increasingly large scale models with Keynesian features are recently introduced in the macro literature -for example, for the study of monetary and fiscal policy effects- that are solved by a first and second order approximations about some steady-state, see DYNARE as developed by Juillard (1996). Large scale macro models, in particular for policy evaluations, have recently made much progress in the application to the U.S. and Euro area economies. Yet to what extent they are accurate may still be an important question; see Becker et al. (2007).
} 
move beyond this acceptance and return, concerning the major issues, to Keynes' thinking. Keynes was responding to classical economics. We have attempted to elaborate how Keynes would have responded to the DGE model. Many topics not only can be enriched with Keynes' ideas, but the overall role that Keynes has assigned to the role of the future, decision under imperfect knowledge and market constraints as well as to the difference of individual and social choice are important and lasting elements in Keynesian theory. We do not have to fall into the trap that the past does not count, but only expectations of future paths are relevant. As our epigraph at the beginning shows, the past is important as well since it has locked us in into expectations, which were formed in the past, ${ }^{26}$ and economic decisions of the past, becoming also a determining structure for the present. ${ }^{27}$

${ }^{26}$ Keynes gives an example of this type of expectations when he mentions that "past expectations... are embodied in the to-day`s capital equipment..." (Keynes, 1936:50).

${ }^{27}$ Recently it has been discovered that purely forward-looking models do fail, too. 


\section{Appendix 1}

The classical postulates and the non-clearing of the labor market

Keynes, in the General Theory, already criticized the two classical postulate according to which the labor market is cleared (see Keynes, 1936: Ch. 2). The first is that the wage is equal to the marginal product. The second is that the disutility of work is brought into line with the utility of the real wage.

Modern intertemporal decision theory has similarly formulated three conditions resulting also in a cleared labor market. Those conditions are the result of first order conditions and Euler equations and they come into existence as a result of frictionless, smooth and unrestricted consumption - leisure (employment) choice where economic agents can, in an intertemporal setting, freely and smoothly trade off consumption, leisure and employment. ${ }^{28}$ Indeed, in the context of the smooth and unconstrained intertemporal choice of modern equilibrium theory, there are three marginal conditions that ensure three equilibria to be established. These are

- the Euler equation that ensures an equality in the intertemporal trade-off of consumption in consecutive periods,

- the marginal rate of substitution equal to the real wage (the cost of trading off leisure against consumption is equal to the real wage),

- the optimizing of the firm ensures the equality of the marginal product of labor equal to the real wage.

There have been two Keynesian responses to the above three conditions. The first, originating directly in Keynes, is that there is too much uncertainty to equate those marginal conditions: As to postulate (i), the intertemporal arbitrage between of consumption today and consumption tomorrow faces too much of a change in macroeconomic environment in order to be realistic. The time span is too long to make accurate trade-offs; see Keynes (1936: Ch. 8). As to postulate (ii), Keynes' response was that workers cannot bargain for the real wage, but only for the money wage.

${ }^{28}$ An early doubt of this assumption and an empirical test of this postulate has been undertaken by Mankiw et al. (1985) who state that their empirical results "cast serious doubts on the premise of most classical macroeconomic models that observe a labor supply represents unconstrained choices given opportunities" (p. 241). 
A second response, articulated in our times, is that whereas the establishment of those equalities presumes frictionless labor markets ${ }^{29}$, actual labor markets are sluggishly adjusting. There are not only nominal frictions of adjusting wages as Keynes already had discussed, but also real frictions in labor markets (employment contracts, employment protections, adjustment cost of firms and workers, cost and frustration in finding work, etc), see recent contributions such as Gong and Semmler (2006b) and Blanchard and Gali (2005). As we argue in this paper one possible approach is to allow for wage stickiness and a non-clearing labor market. This would also give rise to the fact that the conditions (i) and (ii) do not hold. ${ }^{30}$

There are now many models where non-clearing labor market could occur, see Malinvaud (1994) and Benassy (1995, 2002). Yet, the latter models of non-clearing markets of the French disequilibrium tradition are mostly static. Moreover, in those studies with nonclearing labor market, an explicit labor demand function is introduced from the perspective of the decision problems of the firms. However, the decision rule with regard to labor supply in these models is often dropped; because the labor supply no longer appears in the welfare function of the household. Consequently, the moments of labor effort become purely demand-determined. Implicitly, the labor supply in the these models with non-clearing labor market is assumed to be given exogenously. ${ }^{31}$

\footnotetext{
${ }^{29}$ As well as product and capital markets.

${ }^{30}$ Recently there are many studies on EU-countries that allow for considerable sluggishness in the labor market. Many of those studies are discussed in Ernst et al. (2006), see also Gali et al. (2003) who have considered the welfare cost for the case when conditions (ii) does not hold, i.e. when the marginal rate of substitution differs from the real wage and thus from the marginal product of labor, given by (iii).

${ }^{31}$ A recent line of research on modeling unemployment in a dynamic optimization framework can be found in the work by Merz (1999) among others, who endogenizes labor demand and labor supply by employing search and matching theory to model the labor market. Yet, as shown recently, the search and matching models have difficulties to capture the volatility of the actual ratio of vacancies and unemployment, and the drift in unemployment rates; see Shimer (2005).
} 


\section{Appendix 2}

The model of multiple equilibria with adjustment cost

The model we present here builds on a standard intertemporal macro model, see King et al. (1988), but goes beyond it. Moreover, it is augmented by a adjustment cost in investment. The state equation for the capital stock takes the form:

$$
K_{t+1}=(1-\delta) K_{t}+I_{t}-Q_{t}
$$

where $K_{t}, I_{t}$ and $Q_{t}$ are respectively the capital stock, investment and adjustment cost, all in real terms; $\delta$ is the depreciation rate. Here we allow

$$
I_{t}=A_{t} K_{t}^{1-\alpha}\left(N_{t} X_{t}\right)^{\alpha}-C_{t}
$$

with $C_{t}$ to be consumption, $N_{t}$ per capita working hours, $A_{t}$ the temporary shock in technology, and $X_{t}$ is the permanent shock (including both population and productivity growth) that follows a growth rate $\gamma$. The model is non-stationary due to $X_{t}$. To transform the model into a stationary version we need to detrend the variables. For this, we divide both sides of Eq. (1) by $X_{t}$ :

$$
k_{t+1}=\frac{1}{1+\gamma}\left[(1-\delta) k_{t}+i_{t}-q_{t}\right]
$$

Above, we have defined $k_{t}, i_{t}$ and $q_{t}$ to be the detrended variables for $K_{t}, C_{t}$ and $Q_{t}: k_{t} \equiv \frac{K_{t}}{X_{t}}, c_{t} \equiv \frac{C_{t}}{X_{t}}$ and $q_{t} \equiv \frac{Q_{t}}{X_{t}}$. In particular,

$$
\begin{aligned}
& i_{t}=A_{t} k_{t}^{1-\alpha}\left(n_{t} \bar{N} / 0.3\right)^{\alpha}-c_{t} \\
& \text { where } c_{t} \equiv \frac{C_{t}}{X_{t}} \text { and } n_{t} \equiv \frac{0.3 N_{t}}{\bar{N}} \text { with } \bar{N} \text { denoting the sample }
\end{aligned}
$$
mean of $N_{t}$.

The detrended adjustment cost $q_{t}$ depend on detrended investment $i_{t}$ :

$$
q_{t}=q\left(i_{t}\right)
$$


Many non-linear forms of $q(i)$ may lead to a multiplicity of equilibria. Here we consider that $q(i)$ takes the logistic form:

$$
q(i)=\frac{q_{0} \exp \left(q_{1} i\right)}{\exp \left(q_{1} i\right)+q_{2}}-\frac{q_{0}}{1+q_{2}}
$$

Note that in Eq. (2) we posit a restriction such that $q(0)=0$. Another restriction is that $q(i)<i$, indicating that the adjustment cost should never be larger than the investment itself. Both restrictions seem reasonable.

Now if the objective function takes the form

$$
\max E_{0} \sum_{t=0}^{\infty} \beta^{t}\left[\log c_{t}+\theta \log \left(1-n_{t}\right)\right]
$$

multiple (three) equilibria are likely to exist given even the standard parameters of intertemporal models. This holds for a wide range of parameters in Eq. (2). The details of this model are given in Gong and Semmler (2006a: Ch. 7).

\section{Appendix 3}

The model of non-clearing labor market with wage stickiness

We shall follow the standard assumptions on identical households and identical firms. There are three commodities in our model and therefore we have three types of prices, the output price $p_{t}$, the wage rate $w_{t}$ and the rental rate of capital stock $r_{t}$. One of them should serve as a numeraire, which we assume to be the output price. This implies that the wage $w_{t}$ and the rental rate of capital stock $r_{t}$ are all measured in terms of the physical units of output.

\section{The wage setting}

At the beginning of period, $t$, the household should first choose the optimal wage $w_{t}^{*}$ by building on the following dynamic optimization problem:

$$
\max _{w_{t}^{*},\left\{_{t+i} j_{i=0}^{\infty}\right.} E_{t}\left[\sum_{i=0}^{\infty}(\xi \beta)^{i} U\left(c_{t+i}, n_{t+i}\right)\right]
$$

subject to 


$$
\begin{aligned}
& k_{t+i+1}=\frac{1}{1+\gamma}\left[(1-\delta) k_{t+i}+f\left(k_{t+i}, n_{t+i}, A_{t+i}\right)-c_{t+i}\right] \\
& w_{t}^{*}=f_{n}\left(k_{t+i}, n_{t+i},{ }_{t+i}\right) .
\end{aligned}
$$

Above, $U(\cdot)$ is the utility function which depends on consumption $c_{t+i}$ and employment $n_{t+i} ; f(\cdot) \equiv A_{t+i} k_{t+i}^{1-\alpha}\left(n_{t+i} \bar{N} / 0.3\right)^{\alpha}$ is the production function in a stationary form, which is implied by Eq. (4); $f_{n}(\cdot)$ in Eq. (5) is the marginal product of labor derived from $f(\cdot) ; \beta$ is the discount factor; $\xi$ is the probability that the wage rate $w_{t}^{*}$ will remain in period $t+1 ;{ }^{32}$ and finally, $E_{t}$ is the expectation operator. Note that here we have assumed that the household knows the production function $f(\cdot)$ and therefore knows the firm's demand curve for labor as expressed in Eq. (5).

Solving this dynamic optimization problem as expressed in Eqs. (3) - (5) will allow us to obtain $w_{t}^{*}$ which depends on the expectation on the technology sequence $\left\{A_{t+i}\right\}_{i=0}^{\infty}{ }^{33}$ Next, in the spirit of Calvo (1983) we presume the existence of adjustment costs entailed by the economy as a whole, and assign a probability $\xi$, that a fraction of wages will be sticky and the other fraction $(1-\xi)$ will be adjusted. This implies a partial adjustment process, such as

$$
w_{t}=\xi w_{t-1}+(1-\xi) w_{t}^{*},
$$

where $w_{t}$ is the actual wage rate at period $t$.

\section{The Decision of the Household}

Given the wage rate as expressed in Eq. (6), the household will decide about its preferences for output demand and factor supply $\left\{c_{t+i}^{d}, i_{t+i}^{d}, n_{t+i}^{s}, k_{t+i+1}^{s}\right\}_{i=0}^{\infty}$. Note that here we have used the superscripts $d$ and $s$ to refer to the agent's desired, or notional, demand and supply. The decision problem for the household to derive its demand and supply can be formulated as

\footnotetext{
${ }^{32}$ Therefore, $\xi^{i}$ is the probability that $w_{t}^{*}$ will remain in period $t+i$.

${ }^{33}$ For further details of this solution, see Gong and Semmler (2006b).
} 
$\max _{\left\{c_{t+i}^{d}, n_{t+i}^{s}\right\}_{i=0}^{\infty}} E_{t}\left[\sum_{i=0}^{\infty} \beta^{i} U\left(c_{t+i}^{d}, n_{t+i}^{s}\right)\right]$

subject to

$$
k_{t+i+1}^{s}=(1-\delta) k_{t+i}^{s}+f\left(k_{t+i}^{s}, n_{t+i}^{s}, A_{t+i}\right)-c_{t+i}^{d} .
$$

For the given technology sequence $\left\{A_{t+i}\right\}_{i=0}^{\infty}$, Eqs. (7) and (8) form a standard intertemporal decision problem. The solution to this problem can be written as:

$$
\begin{aligned}
& c_{t+i}^{d}=G_{c}\left(k_{t+i}^{s}, A_{t+i}\right) ; \\
& n_{t+i}^{s}=G_{n}\left(k_{t+i}^{s}, A_{t+i}\right) .
\end{aligned}
$$

We shall remark that although the solution appears to be a sequence $\left\{c_{t+i}^{d}, n_{t+i}^{s}\right\}_{i=0}^{\infty}$ only $\left(c_{t}^{d}, n_{t}^{s}\right)$ along with $\left(i_{t}^{d}, k_{t}^{s}\right)$, where $i_{t}^{d}=f\left(k_{t}^{s}, n_{t}^{s}, A_{t}\right)-c_{t}^{d}$ and $k_{t}^{s}=k_{t}$, are actually carried into the market by the household for exchange due to our assumption of reopening of the market.

\section{The decision of the firm}

Since the firm simply rents capital and hires labor on a periodby-period basis, the problem faced by the representative firm at period $t$ is to choose the current input demands and output supplies $\left(n_{t}^{d}, k_{t}^{d}, y_{t}^{s}\right)$ that maximizes the current profit:

$\max y_{t}^{s}-r_{t} k_{t}^{d}-w_{t} n_{t}^{d}$

subject to

$$
y_{t}^{s}=f\left(A_{t}, k_{t}^{d}, n_{t}^{d}\right)
$$

The solution to the above problem will allow us to obtain the demand for inputs:

$$
\begin{aligned}
& k_{t}^{d}=K\left(w_{t}, r_{t}, A_{t}\right) \\
& n_{t}^{d}=N\left(w_{t}, r_{t}, A_{t}\right)
\end{aligned}
$$

while the supply of output is given by Eq. (11).

\section{Transactions in factor market}

Next we shall consider the transactions in our three markets: the capital, labor and product markets. Let us first consider the two factor markets. Given the wage rate $w_{t}$ as expressed in Eq. (6), the rental 
rate of capital $r_{t}$ is adjustable to clear the capital market so that we have

$$
k_{t}=k_{t}^{s}=k_{t}^{d}
$$

This equilibrium condition allows us to obtain $r_{t}$. Given $r_{t}$ as determined by the equilibrium condition Eq. (14) and $w_{t}$ as expressed in Eq. (6), there is no reason to believe that the labor market can be cleared. In this case, we shall have to specify what rule applies regarding the realization of actual employment.

Employment Rules: When a non-clearing of the labor market occurs, either of the following rules might be applied:

$$
\begin{aligned}
& n_{t}=\min \left(n_{t}^{d}, n_{t}^{s}\right), \\
& n_{t}=\omega n_{t}^{d}+(1-\omega) n_{t}^{s} .
\end{aligned}
$$

where $\omega \in(0,1)$.

Above, the first is the famous short-side rule when non-clearing of the market occurs. It has been widely used in the literature on disequilibrium analysis (see, for instance, Benassy 1975, 1984, among others). The second might be called the compromise rule. This rule indicates that when non-clearing of the labor market occurs both firms and workers have to compromise. If there is excess supply, firms will employ more labor than what they wish to employ. ${ }^{34}$ On the other hand, when there is excess demand, workers will have to offer more effort than they wish to offer. ${ }^{35}$ Such mutual compromises may be due to institutional structures and moral standards of the society. Given the rather corporate relationship of labor and firms in Europe, for example, this compromise rule might be considered a reasonable approximation. Such a rule that seems to hold for many other countries was already discussed early in the economic literature, see Meyers (1968) and Solow (1979). See also Ernst et al. (2006) where a test of this rule is performed for many European countries.

\section{The transactions in product market}

\footnotetext{
${ }^{34}$ This could also be realized by firms by demanding the same (or less) hours per worker, but employing more workers than being optimal. This case corresponds to what is discussed in the literature as labor hoarding where firms hesitate to fire workers during a recession because it may be hard to find new workers in the next upswing, see Burnside et al. (1993).

${ }^{35}$ This could be achieved by employing the same number of workers but each worker supplying more hours (varying shift length and overtime work); for a more formal treatment of this point, see Burnside et al. (1993).
} 
After the transactions in these two factor markets have been carried out, the firm will engage in its production activity. The result is the output supply, which, instead of Eq. (11), is now given by

$$
y_{t}^{s}=f\left(k_{t}, n_{t}, A_{t}\right) \text {. }
$$

Then the transaction needs to be carried out with respect to $y_{t}^{s}$. It is important to note that when the labor market is not cleared, the previous consumption plan as expressed by Eq. (9) becomes invalid due to the improper budget constraint, which further bring the improper transition rule of capital Eq. (8), for deriving the plan. Therefore, the household will be required to construct a new consumption plan, which should be derived from the following optimization program:

$$
\max _{\left(c_{t}^{d}\right)} U\left(c_{t}^{d}, n_{t}\right)+E_{t}\left[\sum_{i=1}^{\infty} \beta^{i} U\left(c_{t+i}^{d}, n_{t+i}^{s}\right)\right]
$$

subject to

$$
\begin{aligned}
& k_{t+1}^{s}=(1-\delta) k_{t}+f\left(k_{t}, n_{t}, A_{t}\right)-c_{t}^{d} \\
& k_{t+i+1}^{s}=(1-\delta) k_{t+i}^{s}+f\left(k_{t+i}^{s}, n_{t+i}^{s}, A_{t+i}\right)-c_{t+i}^{d} \\
& i=1,2, \ldots
\end{aligned}
$$

Note that in this optimization program the only decision variable is about $c_{t}^{d}$ and the data includes not only $A_{t}$ and $k_{t}$, but also $n_{t}$, which is given by either Eq. (15) or Eq. (16). We can write the solution in terms of the following equation: ${ }^{36}$

$$
c_{t}^{d}=G_{c 2}\left(k_{t}, A_{t}, n_{t}\right)
$$

Given this adjusted consumption plan, the product market should be cleared if the household demand $f\left(k_{t}, n_{t}, A_{t}\right)-c_{t}^{d}$ for investment. Therefore, $c_{t}^{d}$ in (17) should also be the realized consumption.

The model as demonstrated in Gong and Semmler (2006a: Chs. 8-9) will generate data series that is much more close to the variation of observed time series in comparison with the standard intertemporal model that presume market clearing.

\footnotetext{
${ }^{36}$ See Gong and Semmler (2006: Ch. 8) for details.
} 


\section{References}

Aghion, P., Frydman, R., Stiglitz, J. and Woodford, M. (2003), Knowledge, Information and Expectations in Modern Macroeconomics: In Honor of Edmund S: Phelps, Princeton: Princeton University Press.

Basu, S. and Kimball, M. S. (1997), " Cyclical Productivity with Unobserved Input Variation", NBER Working Paper Series 5915, Cambridge, MA.

BASU, S., Fernald, J. and Kimball, M. S. (1998), "Are Technology Improvement Contractionary?", mimeo. University of Michigan, Ann Arbor.

(1999), "Are Technology Improvement Contractionary?", International Finance Discussion Papers, No. 625, Board of Governors of the Federal Reserve System.

(2006), "Are Technology Improvement Contractionary?", American Economic Review, 96(5),1418-49.

Becker, S., GrüNE, L. and SEMmLER W. (2007), Comparing Accuracy of SecondOrder Approximation and Dynamic Programming" , Computational Economics, 30(1), 65-91, 2007.

Benassy, J.-P. (1995), "Money and Wage Contract in an Optimizing Model of the Business Cycle", Journal of Monetary Economics, 35, 303-15.

(2002), The Macroeconomics of Imperfect Competition and Nonclearing Markets, Cambridge: MIT Press.

BENHABIB, J. and FARMER, R. (1999), "Indeterminacy and Sunspots in Macroeconomics", in J. Taylor and M. Woodford (eds.), Handbook for Macroeconomics, Vol. 1A, New York: North-Holland, 387-448.

Benhabib, J., Schmidt-Grohe. S. and Uribe, M. (2001), "Monetary Policy and Multiple Equilibria", American Economic Review, 91(1), 167-86.

Bernanke, B. and Gertler, M. (1989), "Agency Costs, Net Worth and Business Fluctuations", American Economic Review, 79 (1), 14-31.

Bernanke, B., Gertler, M. and Gilchrist, S. (1998), "The Financial Accelerator in a Quantitative Business Cycle Framework", NBER working paper, no. 6455, also appearing in J. Taylor and M. Woodford (eds), Handbook of Macroeconomics, New York: North-Holland.

Blanchard, O. (2003), "Comments on Jjungqvist and Sargent", in P. Aghion, R. Frydman, J. Stiglitz and M. Woodford (eds.), Knowledge, Information, and Expectations in Modern Macroceconomics, Princeton: Princeton University Press, 351-6.

(2005), "Monetary Policy and Unemployment", in W. Semmler (ed.), Monetary Policy and Unemployment in the US, Euro-area and Japan, New York: Routledge.

Blanchard, O. and QuAH, D. (1987), "Demand and Supply Disturbances", American Economic Review, 79(4), .

BlANCHARD, O. and GALI, J. (2005), "Wage and Price Stickiness", MIT manuscript.

Burnside, A. C., Eichenbaum, M. S. and Rebelo, S. T. (1993), " Labor Hoarding and the Business Cycle", Journal of Political Economy, 101, 245-73.

(1996), "Sectoral Solow Residual", European Economic Review, 40, 861-9.

CAlvo, G.A. (1983), "Staggered Contracts in a Utility Maximization Framework", Journal of Monetary Economics, 12, 383-98. 
Chiarella, C., Franke, R., Flaschel, P. and Semmler, W. (2006) (eds.), Quantitative and Empirical Analysis of Nonlinear Dynamic Macromodels, Amsterdam and New York: Elsevier.

DAY, R. and Young, C. (2004), "Economic Growth and Revealed Social Preference", mimeo. University of Southern California.

ERnst, E., Gong, G., Semmler, W. and Bukericiute, L. (2006), "Quantifying the Impact of Structure Reforms", ECB working paper No. 666, August.

Evans, C. (1992), "Productivity Shock and Real Business Cycles", Journal of Monetary Economics, 29, 191-208.

FARMER (1999), Macroeconomics with Self-Fulfilling Expectations, Cambridge, MIT Press.

Francis, N. and RAMEY, V. A. (2001), "Is the Technology-Driven Real Business Cycle Hypothesis Dead? Shocks and Aggregate Fluctuations Revisited", University of California, San Diego.

FRANCIS, N. and RAMEY, V.A. (2003), "The Source of Historical Economic Fluctuations: An Analysis using Long-Run Restrictions", University of California, San Diego.

FRANKEL, J. (2005), " Financial Crises", manuscript, Harvard University.

Gali, J. and RabAnal, J. (2004), "Technology Shocks and Aggregate Fluctuations", IMF working paper, WP 04/234.

GALI, J. (1999), "Technology, Employment, and the Business Cycle: Do Technology Shocks Explain Aggregate Fluctuation?", American Economic Review, 89 (1), 249-71.

Gali, J., Gertler, M. and. LopeZ-SAlido, J.D (2003), Technology Shocks and Monetary Policy: Assessing the Fed's Performance", Journal of Monetary Economics, 50(4), 723-43.

Gong, G. and SEMmLER, W. (2006a), Stochastic Dynamic Macroeconomics: Theory and Empirical Evidence, New York and Oxford: Oxford University Press.

(2006b), "Wage Stickiness and Nonclearing Labor Market in Business Cycles", www.newschool/gf/cem.

Grüne, L. and Semmler, W. (2004), "Using Dynamic Programming for Solving Dynamic Models in Economics", Journal of Economic Dynamics and Control, 28, 2427-56.

(2005), "Default Risk, Asset Pricing and Debt Control", Journal of Financial Econometrics, 3(1), 79-106.

(2008), "Asset Pricing with Loss Aversion", www.newschool.edu/gf/cem, forthcoming in Journal of Economic Dynamics and Control.

- (2007), "Solving Asset Pricing with Dynamic Programming", Journal of Computational Economics, 29 (3-4), 233-65.

GurLEY, J.G., and SHAW, E.S. (1960), Money in a Theory of Finance, Washington, D.C.: Brookings Institution.

HAHN, F. (1982), "Stability", in K. Arrow and M. Intriligator (eds.), Handbook of Mathematical Economics, Vol. II, New York and Amsterdam: North Holland.

HALl, R. E. (1988), "The Relation between Price and Marginal Cost in U.S. Industry", Journal of Political Economy, 96, 921-47.

JuILlARD, M. (1996), "DYNARE: A Program for the Resolution and Simulation of Dynamic Models with Forward Variables through the Use of a Relaxation Algorithm", CEPREMAP Working Paper, No. 9602, Paris, France. 
KALECKI (1937), "The Principle of Increasing Risk", Review of Economic Studies, November, 441-7.

KATo, M., Ofori, M. and Semmler, W. (2006), "Tobin's q and Investment Model with Multiple Equilibria", in T. Asada and T. Ishikawa (eds.), Time and Space in Economics, Springer-Japan.

Keynes, J. M. (1936), "The General Theory of Employment, Interest and Money", London, MacMillan.

KhemraJ, T., MAdrick, J. and SEMmLER, W. (2006), "Okun's Law and Jobless Growth", New School, SCEPA Policy Notes, March.

KhemraJ, T., ReZAI, A. and SEMmLer, W. (2006), "Productivity and Unemployment in the Short- and Long-Run", interpretation.

KING, R.G. and Wollman, A.L. (1999), "What Should the Monetary Authority do when Prices are Sticky?", in J. Taylor (ed.), Monetary Policy Rules, Chicago: The University of Chicago Press.

LJungQVist, L. and SARgENT, T. (2003), " European Unemployment: From a Worker's Perspective", in P. Aghion, R. Frydman, J. Stiglitz and M. Woodford (eds.), Knowledge, Information, And Expectations in Modern Macroceconomics, Princeton: Princeton University Press, 326-50.

Malinvaud, E. (1994), Diagnosing Unemployment, Cambridge: Cambridge University Press.

Mankiw, N. G. (1989), "Real Business Cycles: A New Keynesian Perspective", Journal of Economic Perspectives, 3, 79-90.

MAnkiw, N.G., Rotemberg J.J. and Summers, L. (1985), "Intertemporal Substitution in Modern Macroeconomics", The Quarterly Journal of Economics, 100(1), 225-51.

MERz, M. (1999), "Heterogenous Job-Matches and the Cyclical Behavior of Labor Turnover", Journal of Monetary Economics, 43, 91-124.

MEYERS, R. J. (1968), "What Can We Learn from European Experience?", in A.M. Ross (ed.), Unemployment and the American Economy, New York: John Wiley \& Sons.

MinSKY, H. (1976), John Maynard Keynes, New York: Columbia University Press. (1978), Can it Happen Again?, New York: M.E. Sharpe.

Pu, C., ReZAI, A. and Semmler, W. (2007), "Productivity and Unemployment in the Short and the Long Run", SCEPA Working Papers 2007-8, New School University.

RICHARDSON, G. B. (1960), Information and Investment, Oxford: Oxford University Press.

Rotemberg, J. (1982), "Sticky Prices in the United States", Journal of Political Economy, 90, 1187-211.

Rotemberg, J. and WoODFord, M. (1995), "Dynamic General Equilibrium Models with Imperfectly Competitive Product Markets," in T.F. Cooley (ed.), Frontiers of Business Cycle Research, Princeton:Princeton University Press.

(1999), "Interest Rate Rules in an Estimated Sticky Price Model", in J. Taylor (ed.), Monetary Policy Rules, Chicago: The University of Chicago Press.

SCHMIDT-GroHE, S. (2000), "Endogenous Business Cycles and the Dynamics of Output, Hours and Consumption", American Economic Review, 90(5), 1136-59. 
SCHMIDT-GRoHe, S. and URIBE M. (2004), "Solving Dynamic General Equilibrium Mideks Using a Second-Order Approximation to the Policy Function" , Journal of Economic Dynamics and Control, 28, 755-75.

SEMmler, W. (2006), Asset Prices, Booms and Recessions: Financial Economics from a Dynamic Perspective (2nd edition), Berlin: Springer.

SEMmler, W., ZhANG, W. and GreINER, A. (2005), Monetary and Fiscal Policies in the Euro-Area: Macro Modelling, Learning and Empirics, Amsterdam and New York: Elsevier.

SHIMER, R. (2005), "The Cyclical behavior of Equilibrium Unemployment and Vacancies", The American Economic Review, 95(1), 25-49.

Solow, R. (1979), "Another Possible Source of Wage Stickiness", Journal of Macroeconomics, 1, 79-82

Stokey, N. L., LuCAS, R. E. and PrescotT, E. C. (1989), Recursive Methods in Economics, Cambridge: Harvard University Press.

Summers, L. H. (1986), "Some Skeptical Observations on Real Business Cycles Theory", Federal Reserve Bank of Minneapolis Quarterly Review, 10, 23-7.

TAYLOR, J. B. (1999), "Staggered Price and Wage Setting in Macroeconomics", in J. B. Taylor and M. Woodford (eds.), Handbook of Macroeconomics, Volume I, New York: Elsevier Science.

Uhlig, H. (2004), “'Macroeconomics and Asset Markets: Some Mutual Implications", Humboldt University, working paper.

WoOdFORD, M. (2003), Interest and Prices, Princeton: Princeton University Press.

\section{Özet}

Keynes ve çağdaş makroiktisat

Dinamik Genel Denge (DGD) modeli, ya da onun popüler versiyonu sayılabilecek olan Reel Konjonktür Çevrimi modeli, son yıllarda makroiktisadın başat paradigması haline gelmiştir. Günümüzde birçok "Yeni Keynesçi"nin de bu yeni paradigmayı paylaştığı izlenmektedir. Keynes, Genel Teori'sinde çağının egemen iktisat anlayışı olan klasik iktisada tepki göstermiş ve eleştiriler yöneltmişti. $\mathrm{Bu}$ makalede Keynes düşüncesinin makroiktisattaki yeni paradigmayı nasıl karşılayacağı sorgulanmaktadır. Bunun yanında, bellibaşı makroekonomik konular tartışılmakta ve geleneksel Keynesçi modellerle DGD modelleri arasındaki farkların nerelerden kaynaklanabileceği açıklanmaktadır. Ayrıca, bazı Keynesçi görüşlerin çağdaş makroekonomi teorisinin yüzyüze geldiği önemli "bilmece"lerin çözümüne nasıl katkı sağlayabileceğine açıklık getirilmektedir.

Anahtar kelimeler: Keynesgil iktisat, DGD modelleri, temizlenmeyen piyasalar, konjonktür çevrimleri.

JEL sinıflandırmasi: E0, E2, E3, E24. 